\title{
HUBUNGAN KARAKTERISTIK INOVASI DENGAN TINGKAT ADOPSI PETANI TERHADAP KOMPONEN PENGENDALIAN HAMA TERPADU (PHT) PADI SAWAH DI DESA WAKANGKA KECAMATAN KAPONTORI KABUPATEN BUTON
}

\author{
${ }^{1)}$ Wardana, ${ }^{2}$ Siti Elfira \\ Program Studi Agribisnis, Fakultas Pertanian \\ Universitas Muhammadiyah Buton \\ Jl. Betoambari No. 36 Baubau \\ e-mail: wardana@umbuton.ac.id
}

\begin{abstract}
This research was conducted from July to August 2018 in Wakangka Village, Kapontori Subdistrict, Buton Regency, with the aim of knowing the characteristics of innovation consisting of relative advantages, compatibility, complexity, trialability, and observability and types of innovation decisions in SLPHT rice plants; know the level of adoption of SLPHT farmers for integrated pest control components; know the relationship between the characteristics of innovation consisting of relative advantages, compatibility, complexity, trialability and observability, as well as the type of innovation decisions with the level of SLPHT farmers' adoption of the Integrated Pest Management (IPM) component. The number of respondents was 30 who had attended SLPHT. The data analysis technique used is the analysis of the average and standard deviations and Spearman rank correlation test. To find out the difference in the level of adoption of the IPM components of rice between SLPHT and Non-SLPHT farmers using t-test. Based on the results of research and discussion, it is found that the characteristics of innovation of farmers provide a relative advantage for farmers, $60 \%$ of farmers say there is compatibility of innovation with pest control needs, and $40 \%$ of respondents state that innovation is sometimes not according to needs. The adoption rate of SLPHT farmers to the IPM component was $40 \%$ of farmers using varieties of lowland rice according to recommendations, $60 \%$ using superior rice not in accordance with recommendations. For fertilization, 20\% of farmers fertilize according to recommendations, and $80 \%$ of farmers fertilize not according to recommendations. For integrated pest control, $50 \%$ of farmers conduct IPM, the remaining 50\% carry out pest control with certain techniques. For the use of natural enemies, $83.33 \%$ of farmers did not utilize natural enemies, the rest, $16.67 \%$ did not use natural enemies. For routine observations, $90 \%$ of farmers do routine observations but not every week, only $10 \%$ of farmers do every week. And observations made are only part of the observation stages. For the wise use of pesticides, all farmers combine pesticides with other techniques. There is a significant relationship between the characteristics of compatibility innovation with the use of natural enemies as indicated by the sig correlation value is 0.05 smaller. There is a significant relationship between complexity with routine observations which is shown by the correlation sig value is 0.013 smaller 0.05 .
\end{abstract}

Keywords: Relationship, characteristics, innovation, adoption, IPM, farmers, lowland rice 


\begin{abstract}
Abstrak
Penelitian ini dilaksanakan pada Bulan Juli s/d Agustus 2018 di Desa Wakangka Kecamatan Kapontori Kabupaten Buton, dengan tujuan mengetahui karakteristik inovasi yang terdiri dari keuntungan relatif, kompatibilitas, kompleksitas, triabilitas, dan observabiltas serta tipe keputusan inovasi dalam SLPHT tanaman padi; mengetahui tingkat adopsi petani SLPHT terhadap komponen pengendalian hama terpadu; mengetahui hubungan antara karakteristik inovasi yang terdiri dari keuntungan relatif, kompatibilitas, kompleksitas, triabilitas dan observabilitas, serta tipe keputusan inovasi dengan tingkat adopsi petani SLPHT terhadap komponen Pengendalian Hama Terpadu (PHT). Jumlah responden sebanyak 30 yang pernah mengikuti SLPHT. Teknik analisis data digunakan adalah analisis rata-rata dan standar deviasi dan uji korelasi jenjang spearman (rank spearman.) Untuk mengetahui perbedaan tingkat adopsi terhadap komponen PHT tanaman padi antara petani SLPHT dan Non SLPHT menggunakan uji $\mathrm{t}(\mathrm{t}$ - test). Berdasarkan hasil penelitian dan pembahasan diperoleh bahwa karakteristik inovasi petani memberikan keuntungan relatif bagi petani, $60 \%$ petani menyatakan ada kesesuaian inovasi dengan kebutuhan pengendalian hama, dan $40 \%$ responden menyatakan inovasi kadang tidak sesuai dengan kebutuhan. Tingkat adopsi petani SLPHT terhadap komponen PHT sebanyak $40 \%$ petani menggunakan varietas padi sawah sesuai rekomendasi, 60\% menggunakan padi unggul tidak sesuai rekomendasi. Untuk pemupukan, $20 \%$ petani melakukan pemupukan sesuai rekomendasi, dan $80 \%$ petani melakukan pemupukan tidak sesuai rekomendasi. Untuk pengendalian hama terpadu, 50\% petani melakukan PHT, sisanya, yaitu 50\% melakukan pengendalian hama dengan teknik tertentu. Untuk pemanfaatan musuh alami, 83,33\% petani kurang memanfaatkan musuh alami, sisanya, $16,67 \%$ tidak memanfaatkan musuh alami. Untuk pengamatan rutin, $90 \%$ petani melakukan pengamatan rutin tapi tidak tiap minggu, hanya $10 \%$ petani yang melakukan tiap minggu. Dan pengamatan yang dilakukan hanya sebagian tahapan pengamatan. Untuk penggunaan pestisida secara bijak, semua petani mengkombinasikan pestisida dengan teknik lain. Ada hubungan yang signifikan antara karakteristik inovasi kompatibilitas dengan pemanfaatan musuh alami yang ditunjukan dengan nilai sig korelasi adalah 0,05 lebih kecil. Ada hubungan yang signifikan antara kompleksitas dengan pengamatan rutin yang ditunjukan dengan nilai sig korelasi adalah 0,013 lebih kecil 0,05.
\end{abstract}

Kata Kunci: Hubungan, karakteristik, inovasi, adopsi, PHT, petani, padi sawah

\title{
PENDAHULUAN
}

\section{Latar Belakang}

Sejak zaman dahulu peranan komoditi pangan di Indonesia, khususnya padi begitu besar, sebab padi merupakan bahan makanan pokok bagi sebagian besar penduduk Indonesia. Kebutuhan bahan pangan berupa padi tidak pernah surut, melainkan kian bertambah dari tahun ke tahun sesuai dengan pertumbuhan penduduk. Untuk mengimbangi dan mengatasi kebutuhan pangan yang semakin meningkat, petani diharapkan dapat bekerja keras guna meningkatkan dan melipat-gandakan produksi bahan pangan padi.

Faktor-faktor pengendalian hama penyakit dalam budidaya tanaman padi memegang peranan penting. Bagaimanapun suburnya tanah, cocoknya iklim, unggulnya bibit atau ketepatan pemupukan tanaman tidak akan memberikan hasil panen yang memuaskan bila terserang hama dan penyakit. Kadang akibatnya tidak hanya kegagalan panen, tetapi juga 
matinya tanaman sehingga kerugiannya sangat besar. Apalagi investasi di bidang pertanian saat ini dilakukan secara besar-besaran. Tak pelak lagi pemahaman dan penguasaan tentang hama dan penyakit mutlak diperlukan (Pracaya, 2004).

Salah satu cara untuk mengatasi kendala serangan hama dan penyakit tanaman yang sering digunakan oleh petani adalah dengan penggunaan pestisida, namun penggunaan pestisida secara terus menerus dan berlebihan akan menimbulkan dampak yang kurang baik bagi tanaman dan lingkungan, seperti munculnya hama resisten, hama-hama sekunder, dan masalah pencemaran lingkungan. Maka dari itu diperlukan adanya suatu teknik pengendalian yang tetap memperhatikan aspek lingkungan yang dikenal dengan Pengendalian Hama Terpadu (PHT).

Pengendalian Hama Terpadu (PHT) adalah teknologi pengendalian hama dengan pendekatan komperhensif berdasarkan ekologi yang dalam keadaan lingkungan tertentu mengusahakan pengintegrasian berbagai taktik tertentu yang kompetibel satu sama lain, sehingga populasi hama dapat dipertahankan dibawah jumlah-jumlah yang secara ekonomis tidak merugikan, mempertahankan kelestarian lingkungan dan menguntungkan bagi petani (Oka, 1995).

Sehubungan dengan hal tersebut diatas perlu dilakukan pembinaan pengendalian OPT pada tanaman padi dengan Metode PHT melalui kegiatan Sekolah Lapang Pengendalian Hama Terpadu (SLPHT), dimana petani dilatih untuk mengelola tanaman atau OPT dengan memadukan beberapa teknik pengendalian yang harmonis dan kompatibel.

Peningkatkan produksi padi secara berkelanjutan petani harus mengadopsi Pengendalian Hama Terpadu padi sawah. Menurut Rogers (1971) dan Van den dan Hawkins (1999) adopsi adalah proses mental dalam pengambilan keputusan untuk menerima atau menolak ide baru. Mardikanto (1993) mengartikan adopsi dalam penyuluhan pertanian sebagai proses perubahan prilaku baik berupa pengetahuan, sikap maupun keterampilan pada diri seseorang setelah menerima inovasi yang disampaikan oleh penyuluh pertanian. Meskipun sistem Pengendalian Hama Terpadu merupakan solusi untuk meningkatkan produksi tanaman padi tanpa merusak lingkungan, tetapi petani belum tentu mau menerima dan mengadopsi teknologi PHT tersebut. Hal ini dikarenakan berbagai faktor yang mempengaruhi tingkat adopsi inovasi, baik faktor yang berasal dari dalam diri petani (internal) maupun yang berasal dari luar diri petani (eksternal).

Hama dan penyakit tanaman merupakan salah salah faktor yang mempengaruhi produksi padi sawah, jika intensitas serangan hama dan penyakit populasinya tinggi maka akan menyebabkan produksi padi sawah rendah. Berikut data luas tanam, luas panen, produksi dan produktifitas padi sawah di Kabupaten Buton tahun 2015- 2017.

Tabel 1. Luas Tanam, Luas Panen, Produksi dan produktifitas Padi Sawah di Kabupaten Buton Tahun 2015-2017

\begin{tabular}{cccccc}
\hline No. & Tahun & $\begin{array}{c}\text { Luas Tanam } \\
(\mathbf{H a})\end{array}$ & $\begin{array}{c}\text { Luas } \\
\text { Panen }(\text { Ha) }\end{array}$ & $\begin{array}{c}\text { Produksi } \\
\text { (ton) }\end{array}$ & $\begin{array}{c}\text { Produktifitas } \\
\text { (ton/Ha) }\end{array}$ \\
\hline 1 & 2015 & 2016 & 2016 & $11.289,6$ & 5,6 \\
\hline 2 & 2016 & 2141 & 2141 & 10.020 & 4,63 \\
\hline 3 & 2017 & 1988 & 1912 & $8.202,9$ & 4,29 \\
\hline
\end{tabular}

Sumber:Dinas Pertanian Kabupaten Buton, tahun 2017

Berdasarkan Tabel 1 diatas menunjukan bahwa produksi dan produktifitas padi sawah dalam kurun waktu tiga tahun terakhir mengalami penurunan yaitu pada tahun 2015 produksi 
padi sawah sebesar $11.289,6$ ton dengan produktifitas yang dicapai sebesar 5,6 ton/ha mengalami penurunan produksi dan produktifitas pada tahun 2016 yaitu produksi menjadi 10.020 ton dengan tingkat produktifitas sebesar 4,63 ton/Ha demikian halnya pada tahun 2017 terjadi penurunan produksi menjadi 8.202,9 ton dan produktifitas menjadi 4,29 ton/Ha. Hal ini disebabkan karena berkurangnya luas panen. Luas panen yang berkurang ini salah satunya disebabkan oleh adanya serangan hama dan penyakit yang tinggi.

\subsection{Tujuan Penelitian}

Adapun tujuan dilakukan penelitian ini adalah untuk:

1. Mengetahui karakteristik inovasi yang terdiri dari keuntungan relatif, kompatibilitas, kompleksitas, triabilitas, dan observabiltas serta tipe keputusan inovasi dalam SLPHT tanaman padi di Desa Wakangka Kecamatan Kapontori Kabupaten Buton

2. Mengetahui tingkat adopsi petani SLPHT terhadap komponen pengendalian hama terpadu di Desa Wakangka Kecamatan Kapontori Kabupaten Buton

3. Mengetahui hubungan antara karakteristik inovasi yang terdiri dari keuntungan relatif, kompatibilitas, kompleksitas, triabilitas dan observabilitas, serta tipe keputusan inovasi dengan tingkat adopsi petani SLPHT terhadap komponen Pengendalian Hama Terpadu (PHT) di Desa Wakangka Kecamatan Kapontori Kabupaten Buton.

\subsection{Manfaat Penelitian}

Manfaat yang diharapkan dari penelitian ini adalah:

1. Bagi peneliti, merupakan salah satu syarat untuk meraih gelar sarjana di Fakultas Pertanian. Selain itu dari penelitian ini diharapkan akan memperkaya wawasan dan pengetahuan peneliti mengenai pertanian secara umum.

2. Bagi pemerintah dan instansi terkait adalah sebagai bahan pertimbangan pembuat kebijakan pemerintah untuk memajukan kehidupan masyarakat di Indonesia, khususnya petani padi di daerah diadakan penelitian.

3. Bagi peneliti lain dapat digunakan sebagai bahan mbanding dan referansi untuk melakukan penelitian sejenis.

\section{METODE PENELITIAN}

Populasi dalam penelitian ini adalah peserta SLPHT tanaman padi yang ada di Desa Wakangka Kecamatan Kapontori Kabupaten Buton. Responden dalam penelitian ini diambil dengan menggunakan cara sensus yaitu semua unit populasi diambil sebagai sumber data atau informan (Mardikanto, 2001). Jumlah responden yang diambil sebanyak 30 yang pernah mengikuti SLPHT. Jenis dan sumber data menggunakan data primer dan data sekunder. Data primer dalam penelitian ini diperoleh langsung dari petani responden melalui wawancara langsung dengan menggunakan kuesioner yang telah disiapkan. Data sekunder diperoleh dari Badan Pusat Statistik (BPS) Kabupaten Buton, Dinas Pertanian Kabupaten Buton, dan Kantor Kecamatan Kapontori.

Variabel yang diamati pada penelitian ini adalah: 1) Identitas responden: umur, pendidikan, luas lahan dan jumlah tanggungan keluarga; 2) Karateristik inovasi: keuntungan relatif, kompatibilitas, kompleksitas, triabilitas, dan observabilitas; dan 3) Tingkat Adopsi Komponen PHT: budidaya tanaman sehat, pengamatan rutin, pemanfaatan musuh alami, dan penggunaan pestisida secara bijaksana. 
Data yang telah dikumpulkan di lapangan diolah dengan mentabulasikan dan seterusnya dipindahkan kedalam bentuk tabularis sesuai dengan kebutuhan analisis. Untuk mengetahui kecenderungan rata-rata antara faktor yang mempengaruhi tingkat adopsi yang meliputi keuntungan relatif, kompatibilitas, kompleksitas, triabilitas, observabilitas dan tingkat adopsi petani SLPHT digunakan analisis rata-rata dan standar deviasi. Dan untuk mengetahui tingkat signifikansi hubungan antara faktor yang mempengaruhi tingkat adopsi yang meliputi keuntungan relatif, kompatibilitas, kompleksitas, triabilitas, dan observabilitas dengan tingkat adopsi petani dalam kegiatan SLPHT digunakan uji korelasi jenjang spearman (rank spearman).

Kriteria pengambilan keputusan:

- Jika t hitung > t table, maka Ho diterima berarti ada hubungan yang signifikan antara faktor-faktor yang mempengaruhi tingkat

- adopsi dengan tingkat adopsi petani dalam kegiatan SLPHT.

- Jika t hitung $\leq \mathrm{t}$ table, maka Ho ditolak berarti ada hubungan yang tidak signifikan antara faktor-faktor yang mempengaruhi tingkat adopsi dengan tingkat adopsi petani dalam kegiatan SLPHT.

Untuk mengetahui perbedaan tingkat adopsi terhadap komponen PHT tanaman padi antara petani SLPHT dan Non SLPHT menggunakan uji $\mathrm{t}(t$-test). Tes ini digunakan untuk signifikansi perbedaan.

Kriteria pengambilan keputusan:

- Jika t hitung $\geq \mathrm{t}$ tabel maka Ho ditolak, berarti terdapat perbedaan yang signifikan antara tingkat adopsi petani peserta SLPHT dengan non SLPHT.

- Jika $t$ hitung < $t$ tabel maka Ho diterima, berarti tidak terdapat perbedaan yang signifikan antara tingkat adopsi petani peserta SLPHT dengan petani non SLPHT.

\section{HASIL DAN PEMBAHASAN}

\subsection{Identitas Petani Sampel}

Adapun identitas petani sampel dalam penelitian ini meliputi umur, tingkat pendidikan, pengalaman berusahatani dan jumlah tanggungan.

\section{a. Umur Responden}

Berdasarkan Tabel 6 diketahui bahwa sebagian petani responden termasuk dalam usia produktif. Batasan usia produktif menurut Kartomo Wirosoehardjo (1981) adalah penduduk yang berusia antara 15-54 tahun. Petani responden yang paling banyak berusia 41 hingga 54 tahun yaitu sebesar 21 jiwa atau 70\%, dan yang tidak produktif 55 hingga 59 tahun sebanyak 9 jiwa atau 30\%. Umur responden akan mempengaruhi kemampuan kerja fisik dalam mengelola suatu usaha hal ini karena tenaga yang dimiliki seseorang sangatlah berbeda antara satu dengan yang lainnya. Petani pada umumnya yang berusia muda mempunyai kemampuan fisik yang cukup kuat serta semangat yang lebih tinggi dibandingkan petani yang berusia tua. Menurut Soeharjo dan Patong (1984) bahwa kategori umur produktif adalah mulai dari usia 15-54 tahun dan selebihnya masuk umur non produktif. 
Tabel 2. Keadaan Petani Responden Berdasarkan Umur di Desa Wakangka Kecamatan Kapontori Tahun 2018

\begin{tabular}{cccc}
\hline No. & $\begin{array}{c}\text { Golongan Umur } \\
\text { (tahun) }\end{array}$ & $\begin{array}{c}\text { Jumlah } \\
\text { (jiwa) }\end{array}$ & $\begin{array}{c}\text { Persen } \\
(\%)\end{array}$ \\
\hline 1 & $41-54$ & 21 & 70 \\
\hline 2 & $55-59$ & 9 & 30 \\
\hline & Jumlah & 30 & 100 \\
\hline
\end{tabular}

\section{b. Tingkat Pendidikan}

Pendidikan sangatlah dalam kehidupan masyarakat, hal ini dikarenakan pengetahuan yang dimiliki oleh orang yang berpendidikan dan yang tidak pernah mengikuti pendidikan sangatlah jauh berbeda karena memiliki kemampuan serta keterampilan dalam mengatasi dan mencari solusi dari masalah dari masalah yang dihadapi. Kemampuan seseorang sebagian besar ditentukan oleh tingkat pendidikan yang dicapai, baik pendidikan formal maupun non formal. pendidikan. Soeharjo dan Patong (1984), mengatakan bahwa tingkat pendidikan relatif tinggi dan umur yang masih muda menyebabkan seseorang cenderung dinamis yang tercermin dalam cara bekerja dan mudah tidaknya menerima inovasi dan informasi yang baru yang pada akhirnya akan meningkatkan nilai tambah pada usahataninya. Tingkat pendidikan responden pada umumnya tergolong rendah, tingkat pendidikan petani responden yang yang berpendidikan SD sederajat sebanyak 14 jiwa (46,67\%), SLTP sederajat sebanyak 7 jiwa (23,33\%), dan SMA sederajat sebanyak 9 jiwa (30\%). Untuk lebih jelasnya tingkat pendidikan responden dapat dilihat pada Tabel 3 sebagai berikut:

Tabel 3. Keadaan Petani Responden Berdasarkan Tingkat Pendidikan di Desa Wakangka Kecamatan Kapontori Tahun 2018

\begin{tabular}{clccc}
\hline No. & & Tingkat Pendidikan & Jumlah (jiwa) & Persen (\%) \\
\hline 1 & SD & 14 & 46,67 \\
\hline 2 & SMP & 7 & 23,33 \\
\hline 3 & SMA & 9 & 30,00 \\
\hline & Total & 30 & 100 \\
\hline
\end{tabular}

\section{c. Jumlah tanggungan}

Jumlah tanggungan keluarga petani responden terdiri dari istri dan anak ataupun yang lainnya yang biaya hidupnya dibiayai oleh satu kepala keluarga yaitu ayah. Jumlah tanggungan keluarga adalah banyaknya yang tinggal dalam satu keluarga yang secara langsung jadi tanggungan kepala keluarga ataupun yang berada diluar rumah tetapi hidupnya masih menjadi tanggungan kepala keluarga yang bersangkutan (Soehardjo dan Patong, 1984).

Jumlah tanggungan keluarga yang besar disamping mempengaruhi kreatifitas dalam mengelola usahataninya, juga akan mempengaruhi pendapatan dan kesejahteraan keluarga tani itu sendiri. Hal ini dimungkinkan terutama bila jumlah tanggungan keluarga tersebut berada pada golongan usia produktif, sehingga akan memungkinkan tersedianya tenaga kerja yang dapat dimanfaatkan dalam kegiatan usahatani. 
Tabel 4. Keadaan Petani Responden Berdasarkan Jumlah Tanggungan di Desa Wakangka Kecamatan Kapontori Tahun 2018

\begin{tabular}{cccc}
\hline No. & Jumlah Tanggungan & Jumlah (jiwa) & Persen (\%) \\
\hline 1 & $1-3$ & 14 & 46,67 \\
\hline 2 & $4-7$ & 16 & 53,33 \\
\hline & Total & 30 & 100 \\
\hline
\end{tabular}

Tabel 4 menunjukan bahwa jumlah tanggungan keluarga responden terbanyak adalah 47 jiwa sebanyak 16 responden (53,33\%). Selanjutnya pada petani responden dengan jumlah tanggungan 1-3 jiwa sebanyak 14 jiwa atau 46,67\%. Tanggungan keluarga mempunyai peran yang penting dalam kegiatan usahatani padi sawah, hal ini dikarenakan tanggungan keluarga yang banyak dan sudah memasuki usia produktif dapat membantu melakukan kegiatan yang berhubungan dengan usahatani padi sawah sehingga bisa mengurangi biaya atau pengeluaran upah tenaga kerja.

\section{d. Luas Lahan Garapan}

Luas garapan petani dalam berusahatani padi sawah relatif bervariasi, jumlah petani responden yang memiliki luas lahan antara $0,5-1,5$ Ha sebanyak 27 jiwa (90\%); dan sisanya yang memiliki luas lahan antara 1,6 - 2,5 Ha sebanyak 3 jiwa (10\%). Keadaan umum responden semacam ini akan mempengaruhi tingkat pendapatan dalam berusahatani padi sawah. Keadaan responden berdasarkan luas lahan garapan dapat dilihat pada Tabel 5.

Tabel 5. Keadaan Petani Responden Berdasarkan Luas Lahan Garapan di Desa Wakangka Kecamatan Kapontori Tahun 2018

\begin{tabular}{cccc}
\hline No. & Luas Lahan (ha) & Jumlah (jiwa) & Persen (\%) \\
\hline 1 & $0,5-1,5$ & 27 & 90 \\
\hline 2 & $1,6-2,5$ & 3 & 10 \\
\hline & Total & 30 & 100 \\
\hline
\end{tabular}

\section{e. Pengalaman Berusahatani}

Pengalaman berusahatani merupakan salah satu faktor yang sangat mendukung dalam kegiatan usahatani. Semakin tinggi tingkat pengalaman bertani maka semakin baik pula pengelolaan usahataninya. Pengalaman berusahatani yang telah dijalani oleh petani merupakan guru besar yang dapat dijadikan pelajaran dan merupakan sumber pengetahuan yang dapat menunjang petani dalam pengambilan keputusan, juga dapat meningkatkan keterampilan petani itu sendiri. Data pengalaman bertani petani sampel di Desa Wakangka dapat dilihat pada Tabel 6 .

Tabel 6. Keadaan Petani Responden Berdasarkan Pengalaman Berusahatani di Desa Wakangka Kecamatan Kapontori Tahun 2018

\begin{tabular}{cccc}
\hline No. & Pengalaman (Tahun) & Jumlah (jiwa) & Persen (\%) \\
\hline 1 & $6-10$ & 13 & 43,33 \\
\hline 2 & Diatas 10 & 17 & 56,67 \\
\hline & Jumlah & $\mathbf{3 0}$ & $\mathbf{1 0 0}$ \\
\hline
\end{tabular}


Berdasarkan Tabel 6 dapat dilihat bahwa jumlah petani yang mempunyai pengalaman bertani terbesar pada kelompok diatas 10 tahun sebanyak 17 jiwa $(56,67 \%)$ dari jumlah keseluruhan petani sampel yang berada di Desa Wakangka dan untuk pengalaman bertani yang terkecil berada pada kelompok 6-10 tahun yaitu 13 jiwa (43,33\%), hal ini menunjukkan bahwa pengalaman petani sampel cukup lama sehingga dapat dikatakan berpengalaman, sebagaimana dikemukakan oleh Soehardjo dan Dahlan Patong (1994) bahwa seseorang dapat dikategorikan berpengalaman apabila telah menggeluti kegiatan usahataninya selama 5-10 tahun, sedangkan diatas 10 tahun dikategorikan berpengalaman dan kurang dari 5 tahun dikategorikan kurang berpengalaman. Dengan demikian diharapkan petani responden dapat melakukan kegiatan usahataninya dengan baik dalam artian dalam menghadapi permasalahanpermasalahan yang dihadapi dalam berusahatani padi sawah.

\section{Hubungan Karakteristik Inovasi dengan Tingkat Adopsi Komponen Pengendalian Hama Terpadu (PHT)}

Berdasarkan hasil analisis menggunakan aplikasi SPSS versi 20, diperoleh nilai rata-rata dan standar deviasi data kuesioner responden pada Tabel 7 sebagai berikut:

Tabel 7. Nilai Rata-Rata dan Standar Deviasi Data Kuesioner Responden petani Padi Sawah di Desa Wakangka Kecamatan Kapontori Kabupaten Buton

\begin{tabular}{|c|c|c|}
\hline Kelompok Data & Rata-rata & Standar Deviasi \\
\hline \multicolumn{3}{|l|}{ Karakteristik Inovasi } \\
\hline $\begin{array}{ll}- & \text { Keuntungan pelaksanaan inovasi }\end{array}$ & 1,0000 & 0 \\
\hline Kompatibilitas & 1,4000 & 0,49827 \\
\hline Kompleksitas & 1,1667 & 0,37905 \\
\hline Triabilitas & 1,0000 & 0 \\
\hline Observabilitas & 1,0000 & 0 \\
\hline \multicolumn{3}{|l|}{ Tingkat Adopsi Komponen PHT } \\
\hline - $\quad$ Budidaya Tan. Sehat & 1,7048 & 0,17570 \\
\hline Pemanfaatan Musuh Alami & 1,8500 & 0,32563 \\
\hline Pengamatan Rutin & 1,9500 & 0,15256 \\
\hline Penggunaan Pestisida Secara Bijak & 2,0000 & 0 \\
\hline
\end{tabular}

Tabel 7 diatas menunjukan bahwa nilai standar deviasi sebesar 0 , artinya tidak ada variasi jawaban yang diberikan responden, semua responden memberikan jawaban yang sama, yaitu untuk keuntungan pelaksanaan inovasi, triabilitas, observabilitas dan penggunaan pestisida secara bijak. Semua responden menyatakan bahwa inovasi memberikan keuntungan finansial (nilai pilihan 1 pada keuntungan pelaksanaan inovasi adalah ada keuntungan usahatani padi sawah). Semua responden menyatakan bahwa inovasi tersebut mudah dicoba terlebih dahulu dalam ukuran/skala kecil (nilai pilihan 1 pada triabilitas). Karakteristik inovasi lain yang semua responden menjawab sama adalah observabilitas, dimana semua responden menjawab 1 yang artinya inovasi tersebut mudah diamati proses dan hasilnya. Selanjutnya untuk tingkat adopsi komponen PHT yang standar deviasinya sebesar 0 adalah penggunaan pestisida secara bijak, yaitu dalam penggunaan pestisida, semua responden mengkombinasikan penggunaan pestisida dengan teknik pengendalian hama lainnya.

Karakteristik inovasi penerapan teknologi pengendalian hama terpadu dapat dilihat pada Tabel 8 berikut: 
Tabel 8. Rekapitulasi Jawaban Responden pada Karakteristik Inovasi Penerapan Teknologi Pengendalian Hama Terpadu

\begin{tabular}{llcc}
\hline \multicolumn{1}{c}{ Karakteristik Inovasi } & \multicolumn{1}{c}{ Pilihan } & $\begin{array}{c}\text { Jumlah Pemilih } \\
\text { (jiwa) }\end{array}$ & $\begin{array}{c}\text { Persen } \\
(\boldsymbol{\%})\end{array}$ \\
\hline Keuntungan Relatif & Ya & 30 & 100 \\
\hline & kadang-kadang & 0 & 0 \\
\hline Kompatibilitas & Tidak & 0 & 0 \\
\hline & Sesuai & 18 & 60 \\
\hline Kompleksitas & Kadang sesuai & 12 & 40 \\
\hline & Tidak sesuai & 0 & 0 \\
\hline Triabilitas & Mudah & 25 & 83,33 \\
\hline & Sedang & 5 & 16,67 \\
\hline & Sulit & 0 & 0 \\
\hline Observabilitas & Mudah & 30 & 100 \\
\hline & Sedang & 0 & 0 \\
\hline & Sulit & 0 & 0 \\
\hline & Mudah & 30 & 100 \\
\hline
\end{tabular}

Tabel 8 menunjukkan bahwa 100\% responden menyatakan bahwa inovasi memberikan keuntungan relatif bagi petani di Desa Wakangka. Sebanyak 60\% responden menyatakan ada kesesuaian inovasi dengan kebutuhan pengendalian hama padi sawah, dan sebanyak $40 \%$ responden menyatakan inovasi kadang sesuai dengan kebutuhan. Untuk kompleksitas, $83,33 \%$ responden menyatakan inovasi tersebut mudah dimengerti dan dilaksanakan, hanya $16,67 \%$ responden yang menyatakan inovasi tersebut sedang (cukup) untuk dimengerti dan dilaksanakan. Untuk triabilitas, semua responden (100\% responden) menyatakan bahwa inovasi tersebut mudah dicoba terlebih dahulu dalam ukuran/skala kecil, dan untuk observabilitas, semua responden (100\% reponden) menyatakan bahwa inovasi tersebut mudah diamati proses dan hasilnya.

petani Desa Wakangka hanya sebagian yang menggunakan varietas padi sesuai rekomendasi penyuluh pertanian, yaitu sebesar $40 \%$, sisanya $60 \%$ menggunakan varietas unggul tapi tidak sesuai rekomendasi. Untuk pelaksanaan tahapan persemaian, hanya $40 \%$ petani melaksanakan semua tahapan persemaian, $60 \%$ hanya melaksanakan sebagian tahapan persemaian. Sebagian besar responden jarang melakukan seleksi benih karena mereka menganggap penyeleksian benih dengan memasukan benih kedalam larutan abu dapur dan memisahkan antara benih yang terapung dan tenggelam akan memakan waktu dan tenaga sehingga mereka lebih mengambil praktisnya saja dengan langsung memgecambahkan benih dengan melakukan pemeraman antara 1-2 malam. Sebelum menyebarkan benih, petani menyiapkan lahan persemaian terlebih dahulu yaitu dengan memperhatikan kesuburan tanah, cahaya matahari dan pengairannya.

Penggunaan jumlah bibit per lubang, semua petani responden memasukkan 2 hingga 4 bibit pada satu lubang tanam. Bukan 1 bibit 1 lubang seperti yang disarankan penyuluh, karena petani beranggapan semakin banyak bibit yang ditanam semakin banyak pula padi yang akan mereka panen. Untuk melihat besarnya tingkat adopsi komponen PHT pada petani Desa Wakangka dapat dilihat pada Tabel 9 berikut: 
Tabel 9. Rekapitulasi Jawaban Responden pada Tingkat Adopsi Komponen PHT

\begin{tabular}{|c|c|c|c|}
\hline Tingkat Adopsi & Pilihan & $\begin{array}{c}\text { Jumlah } \\
\text { Pemilih } \\
\text { (jiwa) }\end{array}$ & $\%$ \\
\hline \multicolumn{4}{|l|}{ Budidaya Tanaman Sehat } \\
\hline \multirow{3}{*}{$\begin{array}{l}\text { Varietas padi yang } \\
\text { digunakan }\end{array}$} & Sesuai rekomendasi & 12 & 40 \\
\hline & Varietas unggul tapi tidak sesuai rekomendasi & 18 & 60 \\
\hline & Bukan varietas unggul & - & 0 \\
\hline \multirow{3}{*}{ 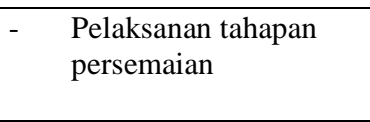 } & Seluruh tahapan dilakasanakan & 12 & 40 \\
\hline & Sebagian tahapan dilaksanakan & 18 & 60 \\
\hline & Tidak melakukan tahapan persemaian & - & 0 \\
\hline \multirow{3}{*}{$\begin{array}{l}\text { Jumlah bibit per } \\
\text { lubang }\end{array}$} & 1 bibit perlubang & - & 0 \\
\hline & 2-4 bibit perlubang & 30 & 100 \\
\hline & 5-6 bibit perlubang & - & 0 \\
\hline \multirow{3}{*}{$\begin{array}{l}\text { - Pengaturan jarak } \\
\text { tanam }\end{array}$} & Menggunakan sistem pengaturan jarak tanam & 3 & 10 \\
\hline & $20 \times 20 \mathrm{~cm}$ & 27 & 90 \\
\hline & Tidak ada pengaturan jarak tanam & - & 0 \\
\hline \multirow[t]{3}{*}{ - $\quad$ Pengairan berselang } & Sesuai anjuran & 14 & 46,67 \\
\hline & Kurang sesuai anjuran & 16 & 53,33 \\
\hline & Tidak melakukan pengairan berselang & - & 0 \\
\hline \multirow[t]{3}{*}{ - $\quad$ Pemupukan } & Sesuai rekomendasi & 6 & 20 \\
\hline & $\begin{array}{l}\text { Dilakukan pemupukan tapi tidak sesuai } \\
\text { rekomendasi }\end{array}$ & 24 & 80 \\
\hline & Tidak melakukan pemupukan & - & 0 \\
\hline \multirow{3}{*}{$\begin{array}{l}\text { Teknik pengendalian } \\
\text { hama terpadu }\end{array}$} & Melakukan secara terpadu & 15 & 50 \\
\hline & Mengendalikan hama dengan teknik tertentu & 15 & 50 \\
\hline & Tidak mengendalikan hama & - & 0 \\
\hline \multicolumn{4}{|l|}{ Pemanfaatan musuh alami } \\
\hline \multirow{3}{*}{$\begin{array}{l}\text { - Mengenali jenis musuh } \\
\text { alami }\end{array}$} & $>5$ jenis musuh alami & 14 & 46,67 \\
\hline & $2-5$ jenis musuh alami & 16 & 53,33 \\
\hline & 1 atau tidak tahu jenis musuh alami & - & 0 \\
\hline \multirow{3}{*}{$\begin{array}{l}\text { - Pemanfaatan musuh } \\
\text { alami }\end{array}$} & Memanfaatkan & - & 0 \\
\hline & Kurang Memanfaatkan & 25 & 83,33 \\
\hline & Tidak memanfaatkan & 5 & 16,67 \\
\hline \multicolumn{4}{|l|}{ Pengamatan rutin } \\
\hline \multirow[t]{3}{*}{ - Rutinitas pengamatan } & Seminggu sekali & 3 & 10 \\
\hline & Rutin tapi tidak setiap minggu & 27 & 90 \\
\hline & Tidak melakukan pengamatan rutun & - & 0 \\
\hline \multirow{3}{*}{$\begin{array}{l}\text { Ruang lingkup } \\
\text { pengamatan }\end{array}$} & Seluruh kegiatan dilaksanakan & - & 0 \\
\hline & Hanya sebagian dilaksanakan & 30 & 100 \\
\hline & Tidak melakukan pengamatan rutin & - & 0 \\
\hline \multirow{3}{*}{$\begin{array}{l}\text { Penggunaan pestisida } \\
\text { secara bijak }\end{array}$} & Penggunaan pestisida sebagai alternatif terakhir & - & 0 \\
\hline & Kombinasi pestisida dengan teknik lain & 30 & 100 \\
\hline & Pestisida sebagai alternatif pertama & - & 0 \\
\hline
\end{tabular}

Tabel 9 menunjukan bahwa penggunaan pestisida secara bijak adalah semua petani tidak menjadikan pestisida sebagai alternatif terakhir tetapi mengkombinasikan pestisida dengan teknik lain, alasannya mereka ingin cepat melihat hasil penyemprotan/pemberantasan hama tersebut, jika mengandalkan pemanfaatan musuh alami, sangat lambat terlihat hasilnya karena proses kerja musuh alami dalam mematikan hama dilakukan secara berangsur-angsur tidak langsung mematikan hama.

Pada pengaturan jarak tanam, terdapat $90 \%$ petani mengatur jarak tanam pada ukuran 20x20 cm, sisanya (10\%) menggunakan metode pengaturan jarak tanam, seperti jajar legowo, karena beranggapan bahwa penggunaan sistem itu tergolong rumit. Pada pengairan berselang, sebanyak $46,67 \%$ petani melaksanakan pengairan berselang sesuai anjuran, sisanya $(53,33 \%)$ melakukan pengairan tapi tidak sesuai anjuran, hal ini disebabkan keterbatasan jumlah air 
untuk pengairan. Untuk pemupukan, sebanyak $80 \%$ petani melakukan pemupukan tapi tidak sesuai rekomendasi, hanya $20 \%$ yang melakukan pemupukan sesuai rekomendasi. Hal ini terjadi karena petani mengalami kesulitan untuk mendapatkan pupuk dan keterbatasan modal untuk membeli pupuk. Sedangkan untuk teknik pengendalian hama terpadu, sebagian petani $(50 \%)$ melakukan pengendalian hama secara terpadu, dan sisanya $50 \%$ melaksanakan pengendalian hama dengan teknik tertentu.

Untuk melihat hubungan karakteristik inovasi dengan tingkat adobsi komponen PHT dilakukan analisis korelasi pada data kuesioner responden dan hasilnya dapat dilihat pada Tabel 10 sebagai berikut:

Tabel 10. Nilai korelasi hubungan karakteristik inovasi dengan tingkat adobsi komponen PHT

\begin{tabular}{|c|c|c|c|c|c|}
\hline & & $\begin{array}{c}\text { Budidaya } \\
\text { Tanaman } \\
\text { Sehat }\end{array}$ & $\begin{array}{c}\text { Pemanfaatan } \\
\text { Musuh } \\
\text { Alami } \\
\end{array}$ & $\begin{array}{c}\text { Pengamatan } \\
\text { Rutin }\end{array}$ & $\begin{array}{c}\text { Penggunaan } \\
\text { Pestisida Secara } \\
\text { Bijak } \\
\end{array}$ \\
\hline \multirow[t]{2}{*}{ Keuntungan } & $\begin{array}{l}\text { Korelasi } \\
\text { Pearson }\end{array}$ & - & - & - & - \\
\hline & Nilai Sig. & - & - & - & - \\
\hline \multirow[t]{2}{*}{ Kompatibilitas } & $\begin{array}{l}\text { Korelasi } \\
\text { Pearson }\end{array}$ & 0,045 & $-0,361^{*}$ & $-0,181$ & - \\
\hline & Nilai Sig. & 0,813 & 0,050 & 0,337 & - \\
\hline \multirow[t]{2}{*}{ Kompleksitas } & $\begin{array}{l}\text { Korelasi } \\
\text { Pearson }\end{array}$ & 0,247 & 0,070 & $-0,447^{*}$ & - \\
\hline & Nilai Sig. & 0,189 & 0,714 & 0,013 & - \\
\hline \multirow[t]{2}{*}{ Triabilitas } & $\begin{array}{l}\text { Korelasi } \\
\text { Pearson }\end{array}$ & - & - & - & - \\
\hline & Nilai Sig. & - & - & - & - \\
\hline \multirow[t]{2}{*}{ Observabilitas } & $\begin{array}{l}\text { Korelasi } \\
\text { Pearson }\end{array}$ & - & - & - & - \\
\hline & Nilai Sig. & - & - & - & - \\
\hline
\end{tabular}


Tabel 10 memperlihatkan terdapat beberapa nilai korelasi yang dapat ditampilkan, yaitu untuk hubungan kompatibilitas dengan budidaya tanaman sehat, kompatibilitas dengan pemanfaatan musuh alami, kompatibilitas dengan pengamatan rutin, kompleksitas dengan budidaya tanaman sehat, kompleksitas dengan pemanfaatan musuh alami dan kompleksitas dengan pengamatan rutin. Kelompok data yang lain tidak ada karena tidak ada variasi data (nilai standar deviasi keuntungan, triabilitas, observabilitas dan penggunaan pestisida secara bijak sebesar 0). Jika standar deviasi suatu kelompok data bernilai 0 maka pasti akan terjadinya error akibat pembagian 0 pada perhitungan nilai korelasi Pearson.

Berdasarkan nilai sig pada Tabel 10 terlihat hanya terjadi hubungan nyata antara karakteristik inovasi kompatibilitas dengan pemanfaatan musuh alami (nilai sig lebih kecil atau sama dengan 0,05 , dalam hal ini sebesar 0,05 ) dan kompleksitas dengan pengamatan rutin (nilai sig lebih kecil 0,05, yaitu sebesar 0,013). Arti adanya hubungan kompatibilitas dengan pemanfaatan musuh alami adalah karakteristik teknologi inovasi pengendalian hama terpadu yang sesuai dengan kebutuhan pengendalian hama padi sawah memiliki hubungan nyata dengan tingkat adopsi komponen PHT yaitu pemanfaatan musuh alami. Petani hanya mengenal 2-5 jenis musuh alami dan kurang memanfaatkan musuh alami tersebut sebagai langkah awal pengendalian hama, mereka lebih memilih cara mengkombinasikan pestisida dengan teknik pengendalian hama lainnya, karena cara ini menurut petani lebih sesuai untuk pengendalian hama padi sawah yaitu mudah diamati proses dan hasilnya.

Tingkat adopsi komponen PHT untuk pemanfaatan musuh alami pada Tabel 13 menunjukkan bahwa sebanyak $46,67 \%$ petani mengenali musuh alami hama lebih dari 5 jenis, sisanya 53,33\% hanya mengenali 2 hingga 5 jenis musuh alami hama yang berguna untuk mengendalikan populasi hama secara alami di tanaman padi sawah petani. Sebanyak 83,33\% petani kurang memanfaatkan adanya musuh alami, sisanya $(16,67 \%)$ tidak memanfaatkan musuh alami.

Pengamatan rutin adalah teknik penerapan pengendalian hama dengan melakukan pengamatan secara rutin pada tanaman padi. Sebanyak $90 \%$ petani melakukan pengamatan rutin tapi tidak setiap minggu, dan sisanya $10 \%$ petani yang melakukan pengamatan seminggu sekali. Untuk ruang lingkup pengamatannya, semua petani hanya melakukan sebagian tahapan pengamatan, tidak keseluruhan. Alasan mereka adalah beberapa tahapan pengamatan merepotkan pekerjaan mereka, seperti mengamati ada tidaknya musuh alami hama tanaman padi sawah.

Karakteristik teknologi inovasi pengendalian hama terpadu lain yang memiliki hubungan nyata adalah kompleksitas dengan pengamatan rutin yang memiliki nilai sig 0,013 , lebih kecil dari 0,05 , yaitu kemudahan teknologi inovasi pengendalian hama terpadu untuk dimengerti dan mudah dilaksanakan memiliki hubungan nyata dengan pengamatan rutin, yaitu petani melakukan pengamatan rutin tetapi tidak setiap minggu. Pengamatan rutin yang dilakukan petani walaupun tidak setiap minggu memberikan kemudahan bagi petani untuk menerapkan teknologi inovasi pengendalian hama terpadu.

\section{KESIMPULAN DAN SARAN}

Kesimpulan dari penelitian ini adalah sebagai berikut:

1. Karakteristik inovasi petani padi sawah di Desa Wakangka adalah semua petani menyatakan bahwa inovasi memberikan keuntungan relatif bagi petani, $60 \%$ petani menyatakan ada kesesuaian inovasi dengan kebutuhan pengendalian hama padi sawah, dan $40 \%$ responden menyatakan inovasi kadang tidak sesuai dengan kebutuhan. Untuk kompleksitas sebesar $83,33 \%$ petani menyatakan inovasi tersebut mudah dimengerti dan 
dilaksanakan, dan $16,67 \%$ petani yang menyatakan inovasi tersebut sedang (cukup) untuk dimengerti dan dilaksanakan. Untuk triabilitas, semua petani menyatakan bahwa inovasi tersebut mudah dicoba terlebih dahulu dalam ukuran/skala kecil, dan untuk observabilitas, semua petani menyatakan bahwa inovasi tersebut mudah diamati proses dan hasilnya.

2. Tingkat adopsi petani SLPHT terhadap komponen PHT tanaman padi sawah di Desa Wakangka adalah $40 \%$ petani menggunakan varietas padi sawah sesuai rekomendasi, $60 \%$ menggunakan padi unggul tidak sesuai rekomendasi. Untuk persemaian sebesar $40 \%$ melaksanakan semua tahapan persemaian, dan $60 \%$ hanya melaksanakan sebagian tahapan persemaian. Semua petani memasukan 2 hingga 4 bibit per lubang pada saat persemaian. Pada pengaturan jarak tanam terdapat $90 \%$ petani mengatur jarak tanam pada ukuran $20 \times 20 \mathrm{~cm}$, sisanya menggunakan $10 \%$ metode lain. Untuk pengairan berselang sebanyak $46,67 \%$ petani melaksanakan pengairan berselang sesuai anjuran dan 53,33\% melakukan pengairan berselang tapi tidak sesuai anjuran. Untuk pemupukan, $20 \%$ petani melakukan pemupukan sesuai rekomendasi, dan $80 \%$ petani melaukan pemupukan tidak sesuai rekomendasi. Untuk pengendalian hama terpadu, 50\% petani melakukan PHT, sisanya, yaitu 50\% melakukan pengendalian hama dengan teknik tertentu. Untuk pemanfaatan musuh alami, 83,33\% petani kurang memanfaatkan musuh alami, sisanya, $16,67 \%$ tidak memanfaatkan musuh alami. Untuk pengamatan rutin, $90 \%$ petani melakukan pengamatan rutin tapi tidak tiap minggu, hanya $10 \%$ petani yang melakukan tiap minggu. Dan pengamatan yang dilakukan hanya sebagian tahapan pengamatan. Untuk penggunaan pestisida secara bijak, semua petani mengkombinasikan pestisida dengan teknik lain.

3. Ada hubungan yang signifikan antara karakteristik inovasi kompatibilitas dengan pemanfaatan musuh alami yang ditunjukan dengan nilai sig korelasi adalah 0,05 lebih kecil atau sama dengan 0,05. Terdapat hubungan yang signifikan antara kompleksitas dengan pengamatan rutin yang ditunjukan dengan nilai sig korelasi adalah 0,013 lebih kecil 0,05 .

Saran yang dapat disampaikan melalui penelitian ini adalah sebagai berikut:

1. Diharapkan petani yang sudah mengikuti SLPHT lebih aktif untuk mentransfer penggetahuan yang diperolehnya selama mengikuti SLPHT kepada petani non SLPHT.

2. Diharapkan pemerintah agar menyediakan komponen pengendalian agens hayati untuk pengendalian hama dan penyakit.

3. Diperlukan penelitian lebih lanjut untuk meneliti mengenai produktivitas dari penerapan komponen PHT pada tanaman padi.

\section{DAFTAR PUSTAKA}

Mardikanto, T dan Sutarni. 1982. Pengantar Penyuluhan Pertanian dalam Teori dan Praktek. Hapsara. Surakarta

Mardikanto, T. 1993. Penyuluhan Pembangunan Pertanian. UNS Press. Surakarta.

Mosher, A.T. 1987. Menggerakkan dan Membangun Pertanian. Jakarta: CV. Yasaguna.

Oka, I. N dan Bahagiawati, A. H. 1995. Pengendalian Hama Terpadu. Balai Penelitian Tanaman Pangan. Bogor.

Pracaya. 2004. Hama dan Penyakit Tanaman. Penebar Swadaya. Depok

Rogers, M. Everett. 1971. Diffusion of Innovation. Collier Macmillan Publisher. London. 